zen $\operatorname{lon}(2)$

PPPL-2793

UC-427
PREPARED FOR THE U.S. DEPARTMENT OF ENERGY, UNDER CONTRACT DE-AC02-76-CHO-3073

PPPL-2793

INVERSE PROBLEM FOR BREMSSTRAHLUNG RADIATION

BY

K.E. VOSS and N.J. FISCH

October 1991
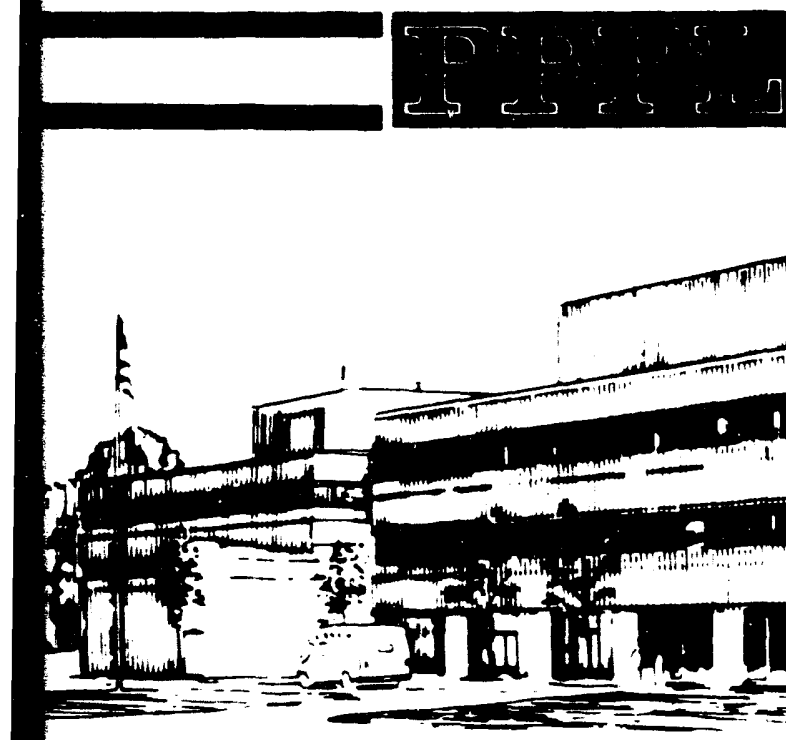

painceton

DLABMA DMYSICS

LABOAATOAY

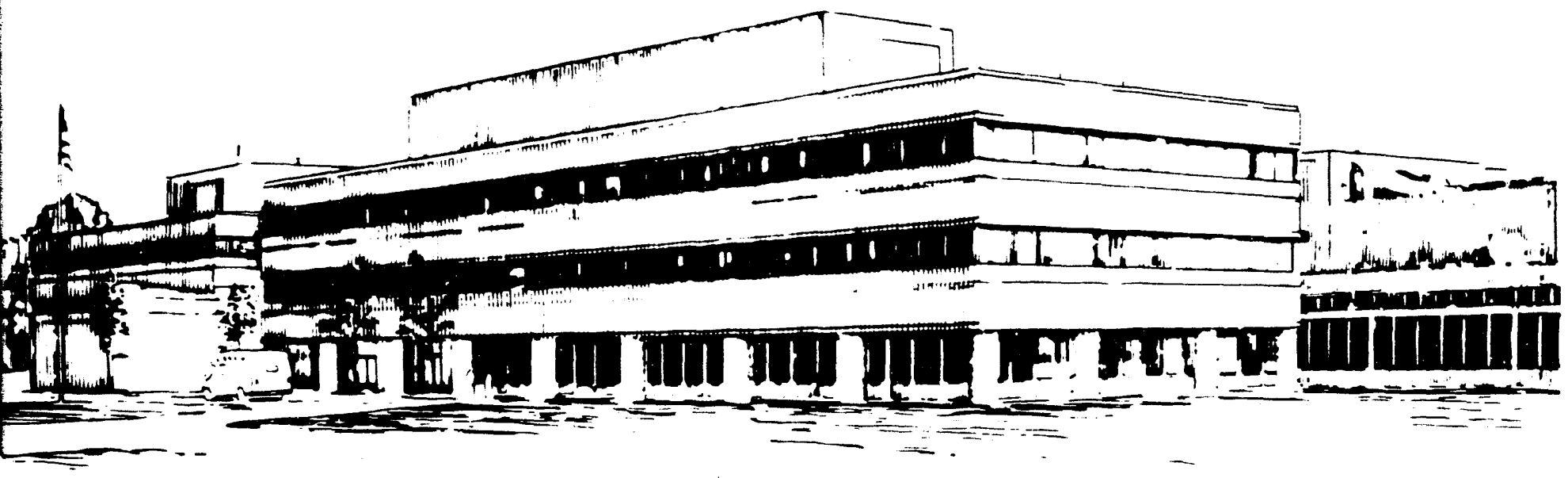




\section{NOTICE}

This report was prepared as an account of work sponsored by an agency of the United States Government. Neither the United States Government nor any agency thereof, nor any of their employees, makes any warranty, express or implied, or assumes any legal liability or responsibility for the accuracy, completeness, or usefulness of any information, apparatus, product, or process disclosed, or represents that its use would not infringe privately owned rights. Reference herein to any specific commercial produce, process, or service by trade name, trademark, manufacturer, or otherwise, does not necessarily constitute or imply its endorsement, recommendation, or favoring by the United States Government or any agency thereof. The views and opinions of authors expressed herein do not necessarily state or reflect those of the United States Government or any agericy thereof.

\section{NOTICE}

This report has been reproduced directly from the best available copy.

Available to DOE and DOE contractors from the:

Office of Scientific and Technical Information P.O. Box 62

Oak Ridge, TN 37831;

Prices available from (615) 576-8401.

Available to the public from the:

National Technical Information Service

U.S. Department of Commerce 5285 Port Royal Road Springfield, Virginia 22161

703-487-4650 


\title{
Inverse Problem for Bremsstrahlung Radiation
}

\author{
K. E. Voss and N. J. Fisch \\ Princeton Plasma Physics Lab
}

July 25, 1991

\section{Abstract}

For certain predominantly one-dimensional distribution functions, an analytic inversion has been found which yields the velocity distribution of superthermal electrons given their Bremsstrahlung radiation.

\section{Paper}

In general, it is not possible to write an analytic expression for the distribution function of electrons simply on the basis of observing their Bremsstrahlung radiation in a plasma. There is a set of circumstances, however, in which just such a data inversion is possible: Consider a homogeneous plasma of electrons and ions of charge $Z_{i}$. The Bremsstrahlung emission at energy $\hbar \omega$ is given by

$$
R(\hbar \omega, \theta) \equiv \frac{d P}{d(\hbar \omega) d \theta}=\int_{v_{\min }}^{\infty} d^{3} \mathbf{v} f(\mathbf{v}) n_{e} n n_{i} v \hbar \omega \frac{d \sigma}{d(\hbar \omega) d \theta}
$$

where $\mathrm{f}(\mathbf{v})$ is the electron distribution function, and $d \sigma / d(\hbar \omega) d \theta$ is the Bremsstrahlung radiation cross-section. If the electrons are non-relativistic, yet are of large enough energy

\section{MASTER}


for the Born approximation to be valid $\left(v \gg c \cdot 2 \pi Z_{i} / 137\right)$, then the cross-section is given by Koch and Motz (1959) as:

$$
\frac{d \sigma}{d(\hbar \omega)}=\frac{16 Z_{i}^{2} r_{0}^{2}}{137} \frac{1}{\hbar \omega} \frac{c^{2}}{v^{2}} \ln \left[\frac{\left(\sqrt{\frac{1}{2} m v^{2}}+\sqrt{\frac{1}{2} m v^{2}-\hbar \omega}\right)^{2}}{\hbar \omega}\right]
$$

In certain cases, the distribution of the most energetic electrons is primarily one dimensional, i.e. $f(\mathbf{v})=f\left(v_{\|}\right)$, where $v_{\|}$might be the dimension along a strong imposed magnetic field. This is the case in tokamak plasmas for a slide-away discharge (Pieroni and Segre, 1975) or for discharges sustained by rf-driven currents (Fisch. 1987). Using Eq. (2) and $f(\mathbf{v})=f\left(v_{\|}\right)$in Eq. (1), we have

$$
R(s)=R_{0} \int_{s}^{\infty} d x f(x) \frac{1}{x} \ln \left[\frac{x}{s}+\sqrt{\frac{x^{2}}{s^{2}}-1}\right]=R_{0} \int_{s}^{\infty} d x f(x) \frac{1}{x} \cosh ^{-1}\left(\frac{x}{s}\right),
$$

where energies are normalized such that: $x^{2} \equiv \frac{1}{2} m v_{\|}^{2}, s^{2} \equiv \hbar \omega$. Note that the lower bound takes into account the cutoff of electrons below the photon energy.

If we now take the derivative of Eq. (3), we get

$$
\frac{d R}{d s}=R_{0} \int_{s}^{\infty} d x f(x)\left[-\frac{1}{s} \frac{1}{\left(x^{2}-s^{2}\right)^{1 / 2}}\right]=\frac{R_{0}}{s} \int_{s}^{\infty} d x\left[\frac{f(x)}{2 x}\right] \frac{2 x}{\left(x^{2}-s^{2}\right)^{1 / 2}} .
$$

which is the familiar form of an Abel invertible equation (Bronshtein and Semendyayev. 1985), so we can invert to yield:

$$
f(x)=\frac{2 x}{R_{0} \pi} \int_{x}^{\infty} \frac{d}{d s}\left(. \frac{d R}{d s}\right) \frac{d s}{\left(s^{2}-x^{2}\right)^{1 / 2}} .
$$

A similar inversion can be made for a distribution which is primarily in the perpendicular direction, e.g. a distribution of highly energetic electrons created by electron cyclotron resonant heating. In this case (where we label the energy as $y^{2} \equiv \frac{1}{2} m v_{\perp}^{2}$ ), the resulting inversion is:

$$
f(y)=\frac{2}{R_{0} \pi} \int_{y}^{\infty} \frac{d}{d s}\left(s \frac{d R}{d s}\right) \frac{d s}{\left(s^{2}-y^{2}\right)^{1 / 2}} .
$$


The restrictiois $\bar{s}$ on this sucessful inversion of Bremsstrahlung data are that of high energy (Born approximation), yet non-relativistic electrons, and a primarily one-dimensional distribution. All three of these conditions can be met by the electrons in an extended tail distribution of a typical tokamak discharge (1-10 keV), where the tail extends to about 5 thermal speeds. Thus it should be possible to apply experimentally this inversion technique. after first subtracting off the background emission from thermal electrons, to determine. for example, the very important features of rf-driven tokamak discharges.

\section{Acknowledgements}

The authors would like to thank George Vetoulis for his comments. This work was supported by the U.S. Department of Energy under contract DE-AC02-76-CHO-3073.

\section{References}

[1] BEKEFI, G. (1966) Radiation Processes in Plasmas, John Wiley and Sons. Inc., New York.

[2] BRONSHTEIN, I. N. AND SEMENDYAYEV, K. A. (1985) Handbook of Mathematics, Van Nostrand Reinhold Company, New York.

[3] FISCH, N. J. (1987) Reviews of Modern Physics 59, 175.

[4] KOCH, H. 'W. and MOTZ, J. W. (1959) Reviews of Modern Physics 31. 920.

[5] PIERONI, L. and SEGRE, S. E. (1975) Physical Review Letters 34, 92S. 
Dr. F. Paoloni, Univ. of Wollongong, AUSTRALIA

Prof. M.H. Brennan, Univ. of Sydnoy, AUSTRALIA

Plasma Research Lab. Australian Nat. Univ., AUSTRALIA

Prof. I.R. Jones, Flinders Univ, AUSTRALIA

Prof. F. Cap, Inst. for Theoretical Physics, AUSTRIA

Prof. M. Heindler, Institut fur Theoretische Physik, AUSTRIA

Prof. M. Goossens, Astronomisch Instituut, BELGIUM

Ecole Royale Militaire, Lab. do Pi y. Plasmas, BELGIUM

Commission-European, DG. XII-Fusioi Prog., BELGIUM

Prof. R. Boucique, Rijksuniversiteit Gent, BELGIUM

Dr. P.H. Sakanaka, Instituto Fisica, BRAZIL

Instituto De Pesquisas Espaciais-INPE, BRAZIL

Documents Office, Alomic Energy of Canada Ltd., CANADA

Dr. M.P. Bectynskj, MPB Technologies, Inc., CANADA

Or. H.M. Skersgerd, Univ. of Sackarchewan. CANADA

Prof. J. Teichmenn, Univ. of Montreal, CANADA

Prof. S.R. Sreenivesan, Univ. of Calgary, CANADA

Prof. T.W. Johnston, INRS-Energie, CANADA

Dr. R. Bolton, Centre canadien de husion magnetique, CANADA

Dr. C.R. James.. Univ. of Nberta, CANADA

Dr. P. Lukec, Komenskeho Universzita, CZECHOSLOVAKIA

The Lbrarian, Culham Laboratory. ENGLAND

Library, R61, Rutherford Appleton Laboratory, ENGLAND

Mrs. S.A. Hutchinson, JET Library, ENGLAND

P. Mahonon, Univ. of Holsinki, FINLAND

C. Mounet, Lab. de Physique des Milieux lonises, FRANCE

J. Radet, CEN/CADARACHE - Bat 506, FRANCE

Ms. C. Rinni, Univ. of loannina, GREECE

Dr. T. Mual, Acaderny Bibliographic Ser., HONG KONG

Preprint Library. Hungerian Academy of Sci., HUNGARY

Dr. B. Das Gupta, Saha Inst. of Nudear Physics, INDIA

Dr. P. Kaw, Inst. for Plasma Rescarch, INDIA

Dr. P. Rosenau, lsreel inst of Technology, ISRAEL

Libravian. Intemational Center for Theo Physics. ITALY

Miss C. De Palo, Associazione EURATOM-ENEA, ITALY

Dr. G. Grosso, Istituto di Fisica del Plasma, ITALY

Dr. H. Yamato, Toshiba Res \& Dovel Contor, JAPAN

Prof. I. Kawakami, Atomic Energy Res.Inst., JAPAN

Prof. K. Nishikawa, Hiroshima Univ., JAPAN
Director, Japan Atomic Energy Research Inst., JAPAN

Prof. S. Itoh, Kyushu Univ., JAPAN

Data and Planning Center, Nagoya Univ., JAPAN

Prof. S. Tanaka, Kyoto Univ., JAPAN

Library, Kyoto Univ., JAPAN

Prof. N. Inove, Univ. of Tokyo, JAPAN

S. Mori, Technical Advisor, JAERI, JAPAN

O. Mitarai, Kumamoto Inst. of Tochnology, JAPAN

H. Jeong. Korea Advanced Energy Research Inst., KOREA

Prof. D.I. Choi, The Korea Adv. Inst. of Sai. \& Tech., KOREA

Prof. B.S. Liby, Univ. of Waikato, NEW ZEALAND

Inst. of Plasma Physics. PEOPLE'S REPUBLIC OF CHINA

Librarian, Inst. of Physics, PEOPLE'S REPUBUC OF CHINA Library. Tsinghua Univ., PEOPLE'S REPUBLIC OF CHINA

Z. L. S.W. Inst Physics, PEOPLE'S REPUBLC OF CHINA

Prof. J.A.C. Cabrd, Instiuto Superior Tecnico, PORTUGAL

Dr. O. Potrus, AL I CUZA Univ., RomanIA

Dr. J. de Villiers, Fusion Suctios, AEC, S. AFRICA

Prof. M.A. Hewberg. Univ. of Natal, S. AFRICA

C.I.E.M.A.T, Fusion Division Library, SPAIN

Dr. L. Slonflo, Univ. of UMEA, SWEDEN

Libray. Royd Inst. of Tectnology, SWEDEN

Prof. H. Wilholmsen, Chalmers Univ. of Tech., SWEDEN

Contre Phys. Des Plasmas, Ecole Polytech, SWIZERLAND

Bibliotheok, Int. Voor Plasma-Fysica, THE NETHERLANDS

M. Durgut, Vice Chairmen, Niddle East Tech. Univ., TURKEY

Dr. D.D. Ryubv. Siberian Brench of Academy of Sci., USSR

Dr. G.A. Eliseov, Kurchabo Inst, USSR

Librerien, The Ukr.SSR Academy of Sciences. USSR

Dr. L.M. Kovrizhnykh, Inst of Generd Physics, USSR

Komforschungeanlege GmbH, Zentrabibliothek, W. GERMANY

Bibliathok, Inet. For Plasmaforectung. W. GERMANY

Prof. K. Schindler, Ruhr-Univorsitht Bochum, W. GERMANY

Dr. F. Wegner, (ASDEX), Max-Planck-Institut, W. GERMANY

Librerian, Max-Planck-Institut, W. GERMANY

Prot. R.K. Janov, Inst. of Physics, YUgosLaVIA 

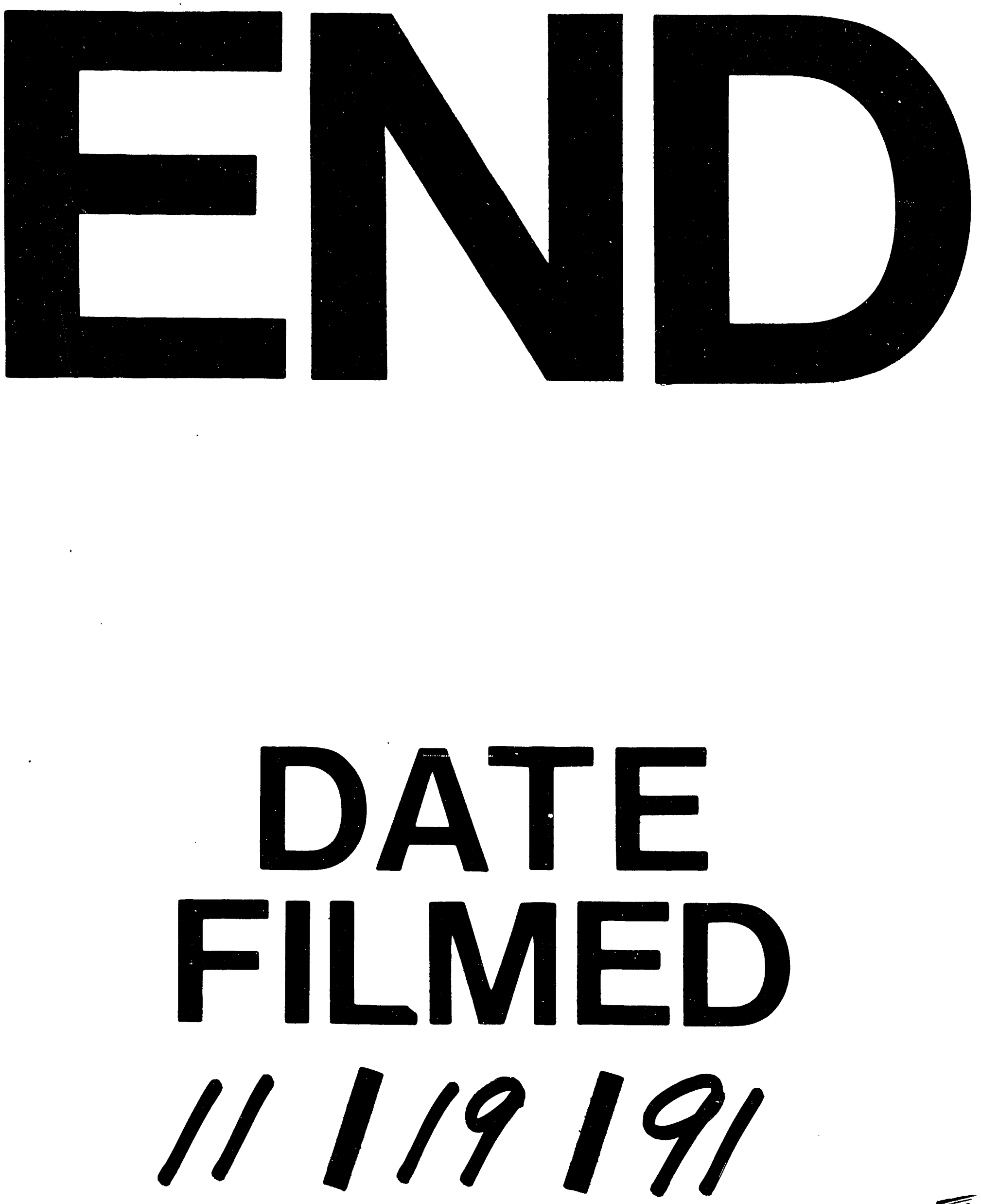

$\overline{1}$ 
